\title{
Food spoilage and Microorganisms
}

\author{
Mustafa Sevindik ${ }^{1, a, *}$, Imran Uysal ${ }^{2, b}$ \\ ${ }^{1}$ Bahçe Vocational High School, Osmaniye Korkut Ata University, 80500 Osmaniye, Turkey \\ ${ }^{2}$ Department of Biology, Faculty of Science and Literature, Gaziantep University, 27410 Gaziantep, Turkey \\ *Corresponding author

\begin{tabular}{l|l} 
A R T I C L E I N F O & A B S T R A C T \\
\hline Review Article & $\begin{array}{l}\text { Microorganisms can spread in extreme conditions. Microorganisms have many beneficial and } \\
\text { harmful effects on human life. In addition to being a disease factor in humans, they also cause } \\
\text { spoilage in food products. Food spoilage is an undesirable process and is a serious problem for } \\
\text { humans. There are many factors that accelerate and affect food spoilage. In this study, microbial } \\
\text { behaviours in foods, microorganisms causing food spoilage and beneficial microorganisms are } \\
\text { mentioned. }\end{array}$ \\
$\begin{array}{l}\text { Received : 30/08/2021 } \\
\text { Accepted : 03/10/2021 }\end{array}$
\end{tabular}

Keywords:

Food spoilage

Microbiology

Bacteria

Fungi

Microbial behaviour

\section{Introduction}

The deterioration of food products is one of the main problems of people. People apply many different methods to prolong the process of food spoilage and increase shelf life. It is estimated that almost half of food losses at the retail and consumer level in developed countries are lost (Burkepile et al., 2006; Amit et al., 2017).

Food spoilage;

- Physical changes (Light, temperature, mechanical damage, etc.)

- Chemical changes (Enzymatic reactions, nonenzymatic reactions, chemical interactions, etc.)

- Food decay

- Microorganism proliferation

- Other elements (Insect, animal, bird, rodent etc.) is caused (Anwer et al., 2017; Sahu et al., 2017). Food spoilage can result in changes in color, taste and nutritional value. There are many different methods to prevent food spoilage.
These;

- Adding sugar and salt,

- Food preservatives

- Packaging

- Processes such as freezing are applied (Martorell et al., 2005; Lorenzo et al., 2018).

\section{Microbial Behaviour in Foods}

\section{Temperature}

Microorganisms according to hot areas; Psychrotrophs are divided into 3 groups: mesophiles and thermophiles. Many of the pathogens on food belong to the group of psychrotrophs. The best temperature range of psychrotrophs is $20-30^{\circ} \mathrm{C}$. The development of mesophiles and thermophiles is prevented by the low temperature effect applied to the products. However, psychrotrophs can be inhibited by internal and external methods (Margesin and Schinner, 1994; Berry and Foegeding, 1997; Oliveira et al., 2015). 


\section{pH}

$\mathrm{pH}$ is a very important parameter for the growth and development of microorganisms. Fungi can grow at lower pH compared to bacteria (Rousk et al., 2009; Jin and Kirk, 2018). Gram negatives are more sensitive to low $\mathrm{pH}$ than Gram positive bacteria. The growth $\mathrm{pH}$ range for fungi is 1.5-9.0. It is 4.0-8.5 for gram positive bacteria. Gram negative bacteria 4.5-9.0. It has the ability to grow in $\mathrm{pH}$ ranges (Hedrich and Schippers, 2021). Microorganisms can be grouped as follows according to their $\mathrm{pH}$ ranges:

- Neutrophiles optimum 5-8 pH

- Acidophiles optimum $\mathrm{pH} 5.5$

- Alkaliphiles optimum pH 8.5

The growth and survival of microorganisms depend on a certain $\mathrm{pH}$ range. The $\mathrm{pH}$ change in these creatures may affect some of them negatively (Booth and Stratford, 2003).

\section{Water Activity}

Water activity is the amount of water required for biological functions that can be reduced by an osmotic effect. Water in food is made available in a variety of ways. Microorganisms need water in an available form to grow in food. The water activity of the food can be expressed as the ratio of the water vapor pressure of the food to the pure water at the same temperature. $>0$ to $<1$ because no food can have a water activity of 0 or 1 (Rahman and Labuza, 2020; Tapia et al., 2020).

Gram negative bacteria need higher water activity than Gram positive bacteria. In general, bacteria require higher water activity than fungi. Most bacteria associated with food spoilage grow above 0.91 , while most filamentous fungi can grow at rates as low as 0.80 (Jay, 2000 Pujaningsih et al., 2021).

\section{Food Microbiology}

Microorganisms can be found in many different food products and can affect the quality and quantity of food. Food products are a very suitable environment for the growth of microorganisms (Mendez et al., 2020). Microorganism growths in food can cause food spoilage or decomposition. In addition, some microorganisms can cause food poisoning when they are in food products (Westerholm et al., 2020). In addition, microorganisms are used in the production of some foods. For example, microorganisms are used in the production of food products such as yoghurt, pickles and cheese (Pathak, 2020).

\section{Microorganisms Causing Deterioration in Foods}

\section{Bacteria}

The spoilage factors in heat-treated foods are especially spore-forming bacterial groups. Bacterial spores can survive even at high temperatures. Gram-positive bacteria can grow in an aerobic and anaerobic environment. They can also tend to grow in high temperatures up to $55^{\circ} \mathrm{C}$ (Rawat, 2015). In this context, some groups of anaerobic bacteria produce hydrogen sulphide during growth in canned/hermetically sealed foods stored at high temperatures. Bacterial groups growing at ambient temperature can cause different spoilage such as rotting of canned products, premature swelling of cheese, production of butyric acid in canned vegetables and fruits (Adams and Moss, 2000; Bintsis, 2017). Bacteria that can grow at low temperatures can produce gas and bad odors in cold meat products, pickled and dried foods. Grampositive bacterial genera that are accepted as food pathogens worldwide are Staphylococcus spp., Clostridium spp., Bacillus spp. and Listeria spp. Gram-negative bacterial genera Salmonella spp, Campylobacter spp, Escherichia spp., Shigella spp., Yersinia spp., Vibrio spp., Aeromonas spp. and Cronobacter spp. are known as food pathogens (Allos, 1997; Adams and Moss, 2000; Jiang et al., 2004; Bintsis, 2017).

\section{Fungi}

Fungi are one of the leading factors of spoilage in food products. Fungi that reproduce by spores are an important factor in the spoilage of many foods under different conditions (Synder et al., 2019). They spread in every layer in different climates and habitats of the world. They are usefully used in the food industry as well as in the pharmaceutical industry (Hernandez and Martinez, 2018). They cause product losses by causing many damages during the harvesting, storage, packaging and processing stages of food products (Kumar and Kalita, 2017). Fungi are agents of fresh fruit and vegetable decay and are a factor in the loss of many post-harvest crops. In developing countries and tropical climatic regions, food losses due to fungi can reach up to 50 percent (Gatto et al., 2011; Shuping and Eloff, 2017; Sevindik, 2018).

Species belonging to Botrytis spp., Penicillium spp., Fusarium spp., Geotrichum spp. and Aspergillus spp. are the spoilage factors of many food products. In addition, mycotoxins produced by fungal species are the leading actors of many diseases. Currently, more than 400 mycoticins have been identified. Aflatoxins, Ochratoxin A, Patulin, Zearalenone, Fumonisins, Trichothecenes and Moniliformin are known mycotoxins. Mycotoxins cause various adverse effects in humans such as intestinal symptoms, allergic responses, immunosuppression, mutagenesis, inhibition of protein synthesis and cancer (Bennett and Klich 2003; Sevindik, 2018).

\section{Protozoa}

Protozoa members are diverse groups of organisms with different ecological niches. The phyla of protozoa that cause disease especially in food-borne humans are Apicomplexa, Rhizopoda, Zoomastigina, Microspora and Ciliophora. Most of them are parasitic. Protozoa, which cause disease in humans, are caused by food and beverage consumption, environmental contamination, and poor hygiene (Yoshida et al., 2011).

\section{Viruses}

Viruses are organisms with complex structures. Viruses that cause many different diseases have more than 10 families. They cause many diseases ranging from partial diarrhea to severe liver disease (Villarreal, 2004; Akhter et al., 2021). There are data available for viruses associated with foodborne gastroenteritis, also known as stomach flu, winter vomiting sickness, diarrhea and vomiting, and infectious intestinal diseases (Woolhouse et al., 2014). Enterovirus, Nipah virus, Poliovirus, Parechovirus, Tickborne encephalitis virus are viruses that are effective on nervous tissue and nervous system (Abdullahi et al., 2020). 
Viruses such as HPAI-H5N1, SARS-CoV are effective on the respiratory system. HAV, HEV has an effect on the liver. NoV, HRV, Sapovirus, Astrovirus, Adenovirus, Aichi virus cause discomfort on the intestinal system (Koopmans and Duizer, 2004; Vasickova et al., 2005; Xu et al., 2020).

\section{Useful Microorganisms in Foods}

Beneficial microorganisms in food products act in different ways. They act by growth, non-growth and byproducts of microorganisms. Yogurt is obtained by the growth of microorganisms through bacteria. The prolongation of the shelf life of raw milk and meat is done by the non-growth of microorganisms. In addition, lactic acid, bacteriocins and some essential amino acids are used in foods as by-products. Consumption of microorganisms with food products such as yogurt can be beneficial for health. Examples of beneficial microorganisms found in food products are Lactobacillus, Streptococcus, Propionibacterium, Saccharomyces, Leuconostoc and Aerobacter (Schleifer, 1985; Sneath, 1986; Ray, 1992)

\section{Conclusion}

In this study, microbial behaviors in foods, microorganisms that cause spoilage in foods and beneficial microorganisms are mentioned. Microbial growth factors that can occur in food products are mentioned. In addition, beneficial and harmful microorganisms found in food products are emphasized.

\section{References}

Abdullahi AM, Sarmast ST, Singh R. 2020. Molecular Biology and Epidemiology of Neurotropic Viruses. Cureus, 12(8): e9674

Adams MR, Moss MO. 2000. Bacterial agents of foodborne illness. In Food Microbiology (pp. 184-271).

Akhter S, Batool AI, Selamoglu Z, Sevindik M, Eman R, Mustaqeem M, Akram MS, Kanwal F, Lu C, Aslam M. 2021. Effectiveness of Natural Antioxidants against SARS-CoV-2? Insights from the In-Silico World. Antibiotics, 10(8): 1011.

Allos BM. 1997. Association between Campylobacter infection and Guillain-Barré syndrome. Journal of Infectious Diseases, 176(Supplement_2): S125-S128.

Amit SK, Uddin MM, Rahman R, Islam SR, Khan MS. 2017. A review on mechanisms and commercial aspects of food preservation and processing. Agriculture \& Food Security, 6(1): 1-22.

Anwer SS, Ali GA, Hamadamin CZ, Jaafar HY. 2017. Isolation and identification of fungi from fast food restaurants in Langa Bazar. International Journal of Environment, Agriculture and Biotechnology, 2(4): 238822.

Bennett JW, Klich M. 2003. Mycotoxins. Clinical Microbiology Reviews, 16: 497-516.

Berry ED, Foegeding PM. 1997. Cold temperature adaptation and growth of microorganisms. Journal of Food Protection, 60: 1583- 1594.

Bintsis T. 2017. Foodborne pathogens. AIMS microbiology, 3(3): 529.

Booth IR, Stratford M. 2003. Acidulants and low pH. In: Russel NJ, Gould GW. (Eds.), Food Preservatives, second, ed. New York, NY: Kluwer Academic/Plenum Publishers, pp. 25-47.

Burkepile DE, Parker JD, Woodson CB, Mills HJ, Kubanek J, Sobecky PA, Hay ME. 2006. Chemically mediated competition between microbes and animals: microbes as consumers in food webs. Ecology, 87(11): 2821-2831.
Gatto MA, Ippolito A, Linsalata V, Cascarano NA, Nigro F, Vanadia S, Di Venere D. 2011. Activity of extracts from wild edible herbs against postharvest fungal diseases of fruit and vegetables. Postharvest Biology and Technology, 61(1): 72-82.

Hedrich S, Schippers A. 2021. Distribution of acidophilic microorganisms in natural and man-made acidic environments. Current issues in molecular biology, 40(1): 25-48.

Hernandez H, Martinez LR. 2018. Relationship of environmental disturbances and the infectious potential of fungi. Microbiology, 164(3): 233.

Jay J. 2000. Modern Food Microbiology, sixth ed. Gaithesburg, MD: AN Aspen Publishers, Inc.

Jiang W, Saxena A, Song B, Ward BB, Beveridge TJ, Myneni SC. 2004. Elucidation of functional groups on gram-positive and gram-negative bacterial surfaces using infrared spectroscopy. Langmuir, 20(26): 11433-11442.

Jin Q, Kirk MF. 2018. pH as a primary control in environmental microbiology: 1. thermodynamic perspective. Frontiers in Environmental Science, 6: 21.

Koopmans M, Duizer E. 2004. Foodborne viruses: an emerging problem. International journal of food microbiology, 90(1): 23-41.

Kumar D, Kalita P. 2017. Reducing postharvest losses during storage of grain crops to strengthen food security in developing countries. Foods, 6(1): 8 .

Lorenzo JM, Munekata PE, Dominguez R, Pateiro M, Saraiva JA, Franco D. 2018. Main groups of microorganisms of relevance for food safety and stability: general aspects and overall description. In Innovative technologies for food preservation (pp. 53-107). Academic Press.

Margesin R, Schinner F. 1994. Properties of cold-adapted microorganisms and their potential role in biotechnology. Journal of Biotechnology, 33(1): 1-14.

Mendez E, Jones C, Trinetta V. 2020. Engaging Undergraduate Students in Food Safety Study and Food Microbiology Research. Food Protection Trends, 40(3): 164-170.

Moatsou G, Moschopoulou E. 2014. Microbiology of raw milk. Dairy Microbiology and Biochemistry, 1-38.

Ijabadeniyi OA, Pillay Y. 2017. Microbial Safety of Low Water Activity Foods: Study of Simulated and Durban Household Samples. Journal of Food Quality, vol. 2017, Article ID 4931521, https://doi.org/10.1155/2017/4931521

Oliveira GBD, Favarin L, Luchese RH, McIntosh D. 2015. Psychrotrophic bacteria in milk: How much do we really know?. Brazilian Journal of Microbiology, 46: 313-321.

P. Martorell MT. 2005. Fernandez-Espinar and A. Querol. Int. J. Food Microbiol, 101: 293-302.

Pathak DV. 2020. Food Microbiology. DOI: 10.13140/RG.2.2.12673.89442.

Pujaningsih RI, Baginda IMT, Sri M, Hilmiyatun N. 2021. Total bacteria, total fungus, and water activity content of multinutrient block with green betle leaf levels added as feed supplements for goat. In IOP Conference Series: Earth and Environmental Science, 667(1): 012027.

Rahman MS, Labuza TP. 2020. Water activity and food preservation. In Handbook of food preservation (pp. 487506). CRC Press.

Rawat S. 2015. Food Spoilage: Microorganisms and their prevention. Asian Journal of Plant Science and Research, 5(4): 47-56.

Ray B. 1992. History of food preservation, in Food Biopreservatives of Microbial Origin, Ray, B. and Daeschel, M.A., Eds., CRC Press, Boca Raton, FL.

Rousk J, Brookes PC, Baath E. 2009. Contrasting soil pH effects on fungal and bacterial growth suggest functional redundancy in carbon mineralization. Applied and Environmental Microbiology, 75(6): 1589-1596.

Sahu M, Bala S. 2017. Food Processing, Food Spoilage and their Prevention: An Overview. Int J Life Sci Scienti Res, 3(1):753-759. 
Schleifer KH, Kraus J, Dvorak C, Kilpper-Blaz R, Collin MD, Fisher W. 1985. Transfer of Streptococcus lactis and related streptococci to the genus Lactococcus genus nov, Syst. Appl Microbiol, 6:183.

Sevindik, M. 2018. Fungal Factors in Food Products Deterioration. Research \& Reviews: Research Journal of Biology, 6(4): 8-11

Shuping DSS, Eloff JN. 2017. The use of plants to protect plants and food against fungal pathogens: A review. African Journal of Traditional, Complementary and Alternative Medicines, 14(4): 120-127.

Sneath PHA. 1986. Ed., Bergey's Manual of Systemic Bacteriology, Vol. 2, Williams \& Wilkins, Baltimore, 1986.

Snyder AB, Churey JJ, Worobo RW. 2019. Association of fungal genera from spoiled processed foods with physicochemical food properties and processing conditions. Food microbiology, 83: 211-218.

Tapia MS, Alzamora SM, Chirife J. 2020. Effects of water activity (aw) on microbial stability as a hurdle in food preservation. Water activity in foods: Fundamentals and applications, 323-355.
Vasickova P, Dvorska L, Lorencova A, Pavlik I. 2005. Viruses as a cause of foodborne diseases: a review of the literature. Veterinární medicína, 50(3): 89.

Villarreal LP. 2004. Are viruses alive?. Scientific American, 291(6): 100-105.

Westerholm M, Liu T, Schnürer A. 2020. Comparative study of industrial-scale high-solid biogas production from food waste: Process operation and microbiology. Bioresource technology, 304: 122981.

Woolhouse M, Scott F, Hudson Z, Howey R, Chase-Topping M. 2012. Human viruses: discovery and emergence. Philosophical Transactions of the Royal Society B: Biological Sciences, 367(1604): 2864-2871.

Xu L, Liu J, Lu M, Yang D, Zheng X. 2020. Liver injury during highly pathogenic human coronavirus infections. Liver international, 40(5): 998-1004.

Yoshida N, Tyler KM, Llewellyn MS. 2011. Invasion mechanisms among emerging food-borne protozoan parasites. Trends in parasitology, 27(10): 459-466. 